Biota Vol. X (1): 36-42, Februari 2005

ISSN 0853-8670

\title{
Pertumbuhan Kaempferia rotunda L. dengan Perlakuan Variasi Jumlah Umbi Semu dan Penambahan Pupuk Organik
}

\author{
The Growth of Kaempferia rotunda L. by Treating Variation of Pseudo-tubers Number \\ and Adding of Organic Fertilizers
}

\section{Ning Wikan Utami}

Lab Treub,Bidang Botani, Puslitbang Biologi-LIPI. Jln Juanda 22-24, Bogor

\begin{abstract}
Kaempferia rotunda, usually called as temu putih is belonging into Zingiberaceae family. This plant has been used as traditional medicine for curing diarrhoe and disentry. Objective of the study was to determine the effect of pseudo tubers number and organic fertilizers on the productivity of $K$. rotunda. Research was conducted in Treub Laboratory, Research Centre for Biology LIPI, Bogor, from July 2002 until April 2003. The experiment was arranged in a factorial Randomized Block Design. The treatments consisted of two factors, i.e the first factor were number of pseudo tubers $(0,2$ and 4$)$ and second factor were organic fertilizers (soil, goat manure and compost).

The result of the exsperiment showed that both factors, i.e number of pseudo tubers and organik fertilizers significantly affect productivity of K.rotunda. The effect of goat manure more dominant than compost. The interaction of those two factors significantly influenced number of leaves and fresh weight of rhizome. The best results was on the combination treatment of two pseudo tubers and goat manure which had the highest value on all peubahs observed which were increased growth and yield of $K$. rotunda significantly.
\end{abstract}

Key words: Kaempferia rotunda L., pseudo tuber, organik fertilizer, productivity

Diterima: 19 Januari 2004, disetujui: 20 April 2004

\section{Pendahuluan}

Kaempferia rotunda atau dikenal juga sebagai kunir putih, kunyit putih merupakan tumbuhan yang termasuk keluarga Zingiberaceae (suku temu-temuan) yang berpotensi obat. Tumbuhan ini mempunyai morfologi yang indah, daunnya berbentuk jorong dengan bagian atas berbelang coklat, bunganya berwarna putih dan berbau harum sehingga selain berkhasiat obat juga mempunyai potensi sebagai tanaman hias dalam pot atau di pekarangan (Backer and Van den Brink, 1968). Seperti pada suku temutemuan lainnya yang bermanfaat obat, kunir putih merupakan salah satu bahan yang digunakan dalam ramuan obat tradisional khususnya di Jawa yang dipercaya menyembuhkan penyakit desentri, diare dan mendinginkan badan (Satroamidjojo, 1977). Rimpang kunir putih yang dicampur dengan jahe, lada dan gula jawa untuk mengobati beberapa penyakit seperti sakit perut, gondongan, obat luka, gangguan tenggorokan Di samping khasiatnya sebagai obat, rimpang kunir putih juga dapat dimanfaatkan untuk bahan kosmetik dan umbinya diduga sebagai bahan penenang (Sastrapradja, 1977). Dilaporkan juga bahwa kunir putih dimanfaatkan sebagai obat dalam yang berkhasiat untuk mempercepat pembekuan darah (Darwis et al., 1991) dan sebagai antiinflamasi (Adjirni dan sa'roni, 2000). Rimpang dan umbinya mengandung minyak atsiri sineol yang beraroma seperti kamfer. Rimpang segar K.rotunda mengandung 0,15\% 
minyakt atsiri dengan komposisi : 3 metil-4 heptanon (21,29); isooktil vinil eter (11,31); B linalool (3,57); DL kamfor (4,35); 4- metal-1 (1 metil etil)- bisiklo 3,1,0; Benzil benzoate $(30,61)$ (Augusta,A.,2000).

Perbanyakan kunir putih seperti yang dilakukan pada suku temu-temuan lainya yaitu menggunakan rimpangnya. Namun rimpang pada kunir putih ini berbeda dengan rimpang pada famili Zingiberaceae umumya yaitu memiliki umbi semu/umbi semu yang berbentuk bulat-oval dan jumlahnya bervariasi. Umbi semu pada $K$. rotunda masih merupakan bagian daripada rimpangnya yang mengandung banyak air sebagai sumber cadangan air pada saat tanaman mengalami kekeringan atau dormansi (Crocket et al., 1971). Sumarni, 2002 melaporkan bahwa bibit/rimpang yang tidak disertai umbi semu menunjukkan pertumbuhan yang lebih lambat dibandingkan dengan yang disertai umbi semu. Penggunaan pupuk organik semakin luas di kalangan pertanian mengingat kelebihannya dibandingkan pupuk kimia. Beberapa keuntungan pupuk organik antara lain adalah dapat meningkatkan ketersediaan beberapa hara makro, kapasitas tukar kation tanah, stabilitas agregat tanah, daya sanggah tanah (buffer), dan aktivitas microorganisme tanah (Nartea, 1990; Marteus dan Frankenberger, 1992). Pupuk kandang sebagai pupuk organik dapat meningkatkan suplai nutrisi bagi tanaman, memperbaiki sifat-sifat fisik tanah yang berhubungan dengan produktivitas tanah, juga sebagai alternatif pengganti pupuk kimia (Hesse, 1984)

Untuk mengetahui pengaruh umbi semu terhadap produktivitas kunir putih dilakukan penelitian dengan perlakuan jumlah umbi semu yang bervariasi dan dikombinasikan dengan penambahan pupuk organik dengan jumlah umbi semu yang optimal dan penambahan pupuk organik yang tepat dapat meningkatkan produktivitas K.rotunda secara maksimal data yang diperoleh diharapkan dapat memberikan tambahan informasi dalam pembudidayaan kunir putih.

\section{Metode Penelitian}

Penelitian dilakukan di Lab. Treub, Puslit. Biologi-LIPI, Bogor dari bulan Juli 2002 sampai April 2003.

Bahan penelitian berupa rimpang kunir putih $(K$. rotunda) yang diperoleh dari daerah Teras, Boyolali dan telah dibudidayakan di lab. Treub, Bogor. Rimpang kemudian dipotongpotong dengan jumlah umbi semu yang berbeda yaitu masing-masing 0 (tanpa umbi semu), 2 umbi semu dan 4 umbi semu masingmasing sebanyak 15 individu. Selanjutnya rimpang tersebut diletakkan di ruang gelap untuk memacu pertumbuhan tunasnya (mematahkan dormansi). Setelah mulai tumbuh tunas $( \pm 2$ bulan) bibit ditanam di dalam pot hitam dengan kapasitas $6 \mathrm{~kg}$ yang berisi media campuran tanah, pupuk kandang dan kompos dengan perbandingan 1:1:1 sebanyak $2 / 3$ bagian. Selanjutnya 2 minggu setelah tanam diberikan perlakuan pemupukan yaitu tanpa pupuk (tanah), pupuk kandang dan kompos sebanyak $1 / 3$ bagian pot $( \pm 2 \mathrm{~kg})$.

Percobaan menggunakan Rancangan Acak Lengkap yang disusun secara faktorial, faktor pertama adalah jumlah umbi semu $(0,2$ dan 4) dan faktor ke dua adalah pemupukan ( tanpa pupuk, pupuk kandang dan kompos). Masing-masing perlakuan 5 ulangan.

Pengamatan pertumbuhan tanaman diamati setiap bulan yang meliputi tinggi bibit, jumlah daun dan jumlah anakan. Pada akhir pengamatan (9 bulan setelah tanam) ditetapkan bobot basah dan kering tajuk, jumlah umbi, bobot basah dan kering rimpang.

\section{Hasil dan Pembahasan}

Pengamatan pertumbuhan $K$. rotunda sejak awal tanam sampai 9 bulan setelah tanam memperlihatkan perbedaan pada kombinasi perlakuan jumlah umbi semu dan penambahan pupuk organik yaitu pada peubah tinggi bibit (Gambar 1), jumlah daun (Gambar 2) dan jumlah anakan/tunas (Gambar 3). Secara umum teramati bahwa kombinasi perlakuan 2 umbi semu dan pupuk kandang (U2P1) menghasilkan pertumbuhan paling baik dibanding dengan perlakuan lain. 


\section{Tinggi tanaman}

Pengamatan tinggi tanaman $K$. rotunda menunjukkan pertumbuhan maksimal pada 7 bulan setelah tanam baik pada perlakuan tanpa umbi semu , 2 maupun 4 umbi semu dan selanjutnya sampai 9 bulan setelah tanam tetap (Gambar 1). Penambahan pupuk organik baik kandang maupun kompos memperlihatkan pertumbuhan yang lebih baik dibandingkan tanpa penambahan pupuk. Pola pertumbuhan tanaman pada umumnya menunjukkan kurva sigmoid dimana pada umur tertentu pertumbuhan vegetatif akan mencapai maksimal yang selanjutnya diikuti pertumbuhan generatif. Khususnya pada keluarga Zingiberaceae terhentinya pertumbuhan vegetatif ditandai dengan tidak bertambahnya tinggi tanaman, jumlah daun dan warna daun mulai menguning, pada fase ini terjadi perkembangan rimpang dan umbi semu. Jumlah umbi semu tidak berpengaruh nyata terhadap tinggi tanaman, sedangkan perlakuan pupuk kandang (pukan) meningkatkan tinggi tanaman secara nyata (Tabel 1). Penambahan pupuk kompos meskipun tidak nyata meningkatkan tinggi tanaman tetapi memiliki angka cenderung lebih tinggi dibandingkan kontrol (tanpa penambahan pupuk). Tinggi tanaman tertinggi diperoleh pada kombinasi perlakuan 2 dan 4 umbi semu dengan penambahan pupuk kandang yaitu $107,17 \mathrm{~cm}$ (U2P1 dan U4P1).

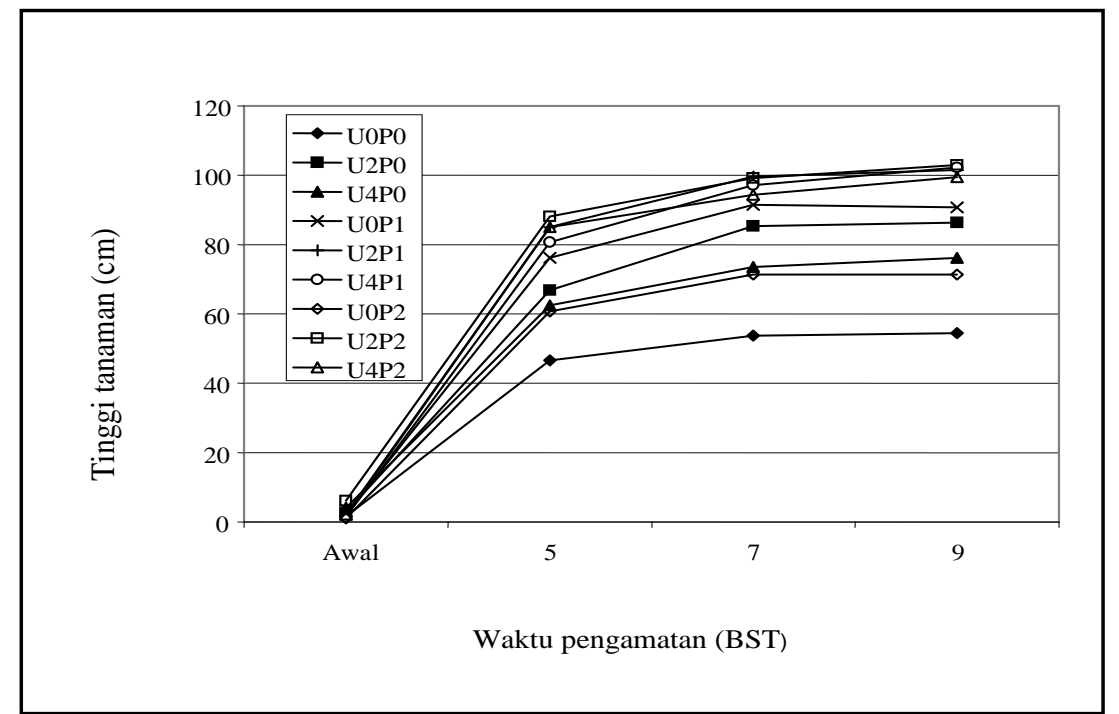

Gambar 1. Laju pertambahan tinggi tanaman $K$. rotunda dengan perlakuan jumlah umbi semu dan pupuk organik.

\section{Jumlah daun}

Seperti pada pertambahan tinggi tanaman, pertambahan jumlah daun terjadi hal yang serupa yaitu jumlah daun terbanyak teramati pada 7 bulan setelah tanam dan selanjutnya nampak menurun baik pada perlakuan tanpa umbi semu, 2 umbi semu maupun 4 umbi semu (Gambar 2). Perlakuan penambahan pupuk organik memiliki jumlah daun lebih banyak dibandingkan tanpa penambahan pupuk, teramati bahwa pupuk kandang cenderung lebih baik dari pada kompos. Menurunnya jumlah daun disebabkan daun sudah mulai banyak yang layu dan kering. Sumarmaini, dkk. 1996 melaporkan bahwa pada tanaman kencur ( $K$. galangal L.) pertambahan jumlah daun mulai menurun pada umur 6 bulan setelah tanam dan selanjutnya daun menguning. Perlakuan jumlah umbi semu dan pupuk organik masing-masing berpengaruh nyata terhadap jumlah daun (Tabel 1). Perlakuan 2 umbi semu, penambahan pupuk kandang dan kompos nyata meningkatkan jumlah daun. Seperti halnya pada peubah tinggi tanaman, jumlah daun tertinggi $(22,33)$ diperoleh pada kombinasi perlakuan 2 umbi semu dan pupuk kandang (U2P1) (Tabel 2). 


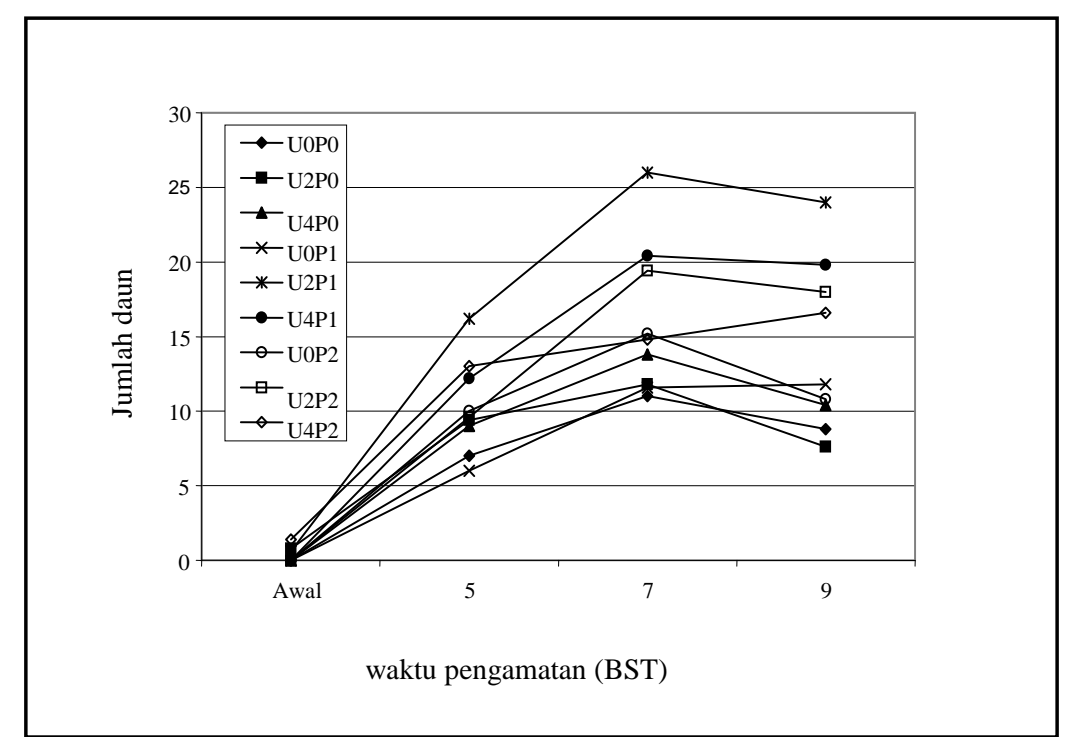

Gambar 2. Laju pertambahan jumlah daun $K$. rotunda dengan perlakuan jumlah umbi semu dan pupuk organik.

\section{Jumlah tunas}

Pengamatan terhadap jumlah tunas sejak 3 bulan sampai 9 bulan setelah tanam nampak adanya pertambahan berkisar antara 2 sampai 4. Secara umum nampak bahwa jumlah tunas pada 7 bulan setelah tanam pada beberapa perlakuan tidak bertambah. Hal ini diduga setelah umur 7 bulan pertambahan jumlah tunas mulai terhambat dan kemudian terhenti yang selanjutnya diikuti dengan perkembangan rimpang. Dilaporkan bahwa setelah 6 bulan tanam pertambahan jumlah tunas mulai menurun dan tidak ada pertumbuhan tunas baru (Sumarmaini dkk, 1996). Pada Gambar 3 nampak jumlah tunas terbanyak $=6,4$ diperoleh pada kombinasi perlakuan 2 umbi semu dan penambahan pupuk kandang (U2P1).

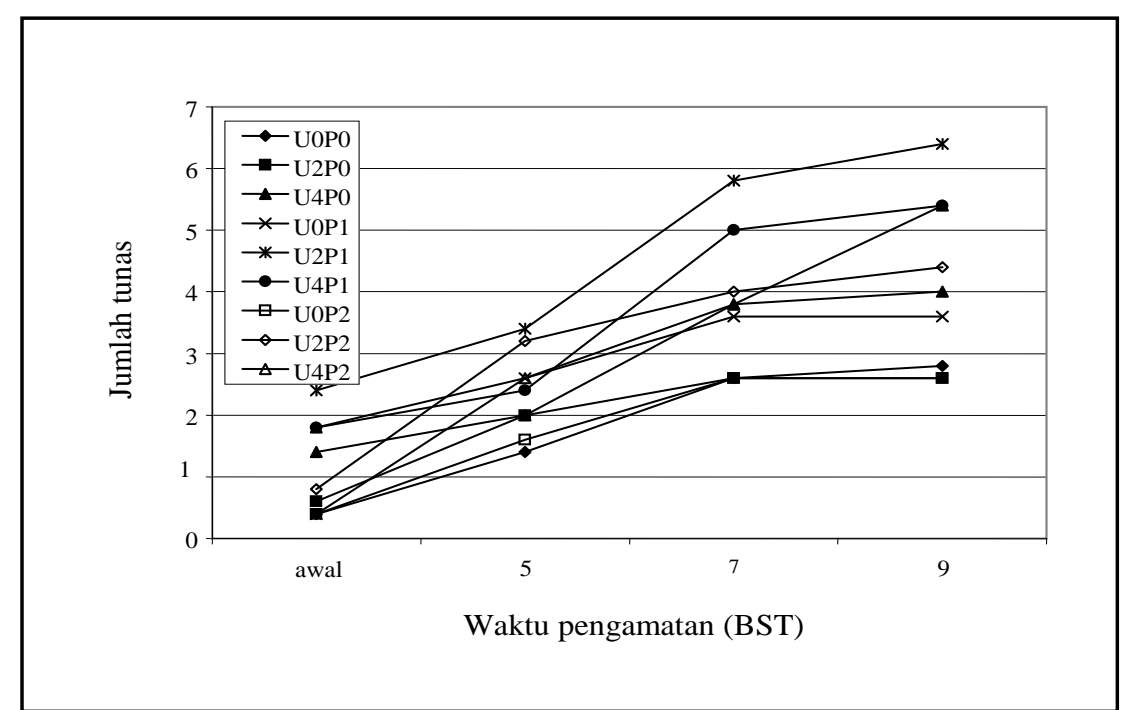

Gambar 3. Laju pertambahan jumlah tunas $K$. rotunda dengan perlakuan jumlah umbi semu dan pupuk organik 
Hasil analisa statistik pada Tabel 1. menunjukkan bahwa perlakuan jumlah umbi semu berpengaruh nyata terhadap semua peubah yang diamati kecuali pada tinggi tanaman dan bobot kering umbi , meskipun tidak nyata meningkatkan tetapi memiliki angka yang cenderung lebih tinggi. Rimpamg yang disertai 2 dan 4 umbi semu meningkatkan produktivitas $K$. rotunda secara nyata. Hasil paling baik nampak pada perlakuan 2 umbi semu yaitu memiliki jumlah daun, jumlah tunas, jumlah umbi, bobot basah dan kering tajuk serta bobot basah umbi tertinggi. Sebaliknya pada perlakuan tanpa umbi semu (0) menunjukkan pertumbuhan paling jelek, nampak pada semua peubah yang diamati memiliki angka terendah dibandingkan dengan perlakuan rimpang yang disertai 2 dan 4 umbi semu. Hasil ini sesuai dengan laporan Sumarni, 2003 dimana pertumbuhan bibit/rimpang $K$. rotunda tanpa disertai umbi semu menunjukkan pertumbuhan yang lebih lambat dibandingkan dengan rimpang yang disertai umbi semu. Pengaruh faktor tunggal pemupukan nampak bahwa penambahan pupuk organik baik pupuk kandang maupun kompos nyata meningkatkan tinggi tanaman, jumlah daun, jumlah anakan, bobot basah daun dan rimpang. Pada peubah jumlah umbi semu, bobot kering tajuk dan umbi meskipun tidak nyata meningkat tetapi ada kecenderungan lebih tinggi dibandingkan tanpa penambahan pupuk organik (Table 1).

Tabel 1. Pengaruh masing-masing faktor jumlah umbi semu dan pupuk organik terhadap produktitivitas kunir putih $(K$. rotunda).

\begin{tabular}{lcccccccc}
\hline \hline Perlakuan & $\begin{array}{c}\text { Tinggi } \\
\text { tanaman } \\
(\mathrm{cm})\end{array}$ & $\begin{array}{c}\text { Jumlah } \\
\text { daun }\end{array}$ & $\begin{array}{c}\text { Jumlah } \\
\text { tunas }\end{array}$ & $\begin{array}{c}\text { Jumlah } \\
\text { Umbi } \\
\text { semu }\end{array}$ & $\begin{array}{c}\text { Bobot } \\
\text { basah } \\
\text { Tajuk }\end{array}$ & $\begin{array}{c}\text { Bobot } \\
\text { krg } \\
\text { Tajuk }\end{array}$ & $\begin{array}{c}\text { Bobot } \\
\text { basah } \\
\text { rimpang }\end{array}$ & $\begin{array}{c}\text { Bobot } \\
\text { kering } \\
\text { rimpang }\end{array}$ \\
\hline \hline Jumlah umbi & & & & & & & & \\
0 & $95,72 \mathrm{a}$ & $11,22 \mathrm{~b}$ & $3,22 \mathrm{~b}$ & $63,67 \mathrm{~b}$ & $152,44 \mathrm{~b}$ & $9,36 \mathrm{~b}$ & $272,81 \mathrm{c}$ & $50,06 \mathrm{a}$ \\
$\quad 2$ & $98,25 \mathrm{a}$ & $18 \mathrm{a}$ & $5,25 \mathrm{a}$ & $89 \mathrm{a}$ & $361,13 \mathrm{a}$ & $25,18 \mathrm{a}$ & $469,01 \mathrm{a}$ & $64,05 \mathrm{a}$ \\
4 & $98,94 \mathrm{a}$ & $14,38 \mathrm{ab}$ & $3,75 \mathrm{~b}$ & $84,13 \mathrm{a}$ & $236,10 \mathrm{~b}$ & $16,04 \mathrm{~b}$ & $372,81 \mathrm{~b}$ & $59,43 \mathrm{a}$ \\
$\begin{array}{c}\text { Pemupukan } \\
\text { Tanpa pupuk }\end{array}$ & $89,78 \mathrm{~b}$ & $12,33 \mathrm{~b}$ & $3,11 \mathrm{~b}$ & $73,11 \mathrm{a}$ & $176,54 \mathrm{~b}$ & $13,54 \mathrm{a}$ & $313,07 \mathrm{~b}$ & $55,28 \mathrm{a}$ \\
Pukan & $104,89 \mathrm{a}$ & $16,56 \mathrm{a}$ & $4,44 \mathrm{a}$ & $84,44 \mathrm{a}$ & $321,36 \mathrm{a}$ & $19,77 \mathrm{a}$ & $402,06 \mathrm{a}$ & $59,97 \mathrm{a}$ \\
kompos & $98,14 \mathrm{ab}$ & $14,29 \mathrm{ab}$ & $4,71 \mathrm{a}$ & $77,14 \mathrm{a}$ & $238,39 \mathrm{ab}$ & $16,30 \mathrm{a}$ & $392,96 \mathrm{a}$ & $57,30 \mathrm{a}$
\end{tabular}

Keterangan: Angka-angka yang diikuti dengan huruf yang sama pada lajur yang sama tidak berbeda nyata pada uji Duncan taraf 5\%.

Hasil analisa statistik nampak adanya interaksi yang nyata antara perlakuan jumlah umbi semu dan penambahan pupuk organik pada peubah jumlah daun dan bobot basah umbi. Kombinasi perlakuan jumlah umbi semu dan penambahan pupuk kandang maupun kompos menghasilkan pertumbuhan yang lebih baik dibandingkan dengan tanpa penambahan pupuk organik. Bahan organik selain berperan memperbaiki struktur tanah menjadi lebih gembur, daya pegang air serta permeabilitas tanah juga meningkatkan ketersediaan hara (Kanonova, 1996). Keadaan tersebut akan meningkatkan kegiatan mikroorganisme tanah (Yufdy,1996).
Mikroorganisme tanah akan merombak bahan organik menjadi unsur-unsur hara yang tersedia dan mudah diserap oleh tanaman (Noggle dan Fritz, 1983). Kompos dapat membuat aerasi tanah yang baik dan struktur tanah menjadi gembur sehingga tanaman dapat berkembang dengan lebih baik dan cukup efektif dalam menyerap unsur-unsur hara (Salisbury \& CW Ross, 1991). Hasil analisa media tanam setelah dilakukan penambahan pupuk organik (Tabel 3) menunjukkan bahwa pada perlakuan penambahan pupuk organik memiliki struktur yang lebih gembur, (kandungan pasir 53,2-55\% dan liat 19,8-20\%) dibandingkan tanpa pupuk 
(pasir 50,4\% dan liat 23,.5\%). Demikian juga kandungan $\mathrm{N}, \mathrm{P}$ dan $\mathrm{K}$ jauh lebih tinggi pada media yang diberikan pupuk organik. Unsurunsur hara makro seperti N,P dan K merupakan unsur penting yang berperan dalam metabolisme dan berpengaruh terhadap produktivitas tanaman.

Pada Tabel 2 dapat dilihat bahwa perlakuan terbaik diberikan pada kombinasi perlakuan 2 umbi semu dengan penambahan pupuk kandang (U2P1) hal ini teramati pada semua peubah yang menunjukkan angka paling tinggi dibandingkan perlakuan lainnya. Penggunaan pupuk kandang juga meningkatkan pertumbuhan dan produksi beberapa jenis tanaman yang termasuk famili zingiberaceae yaitu pada kencur (Sumarmaini,
E., Januwati, M. dan Iskandar, M. 1996) dan jahe (Effendi,D.S. dan Januwati, M. 1996). Dalam hal ini bahan organik tidak hanya untuk menyediakan hara bagi tanaman tetapi yang lebih penting lagi adalah untuk memperbaiki kondisi fisik tanah yang sangat diperlukan bagi perkembangan rimpang. Fungsi bahan organik ini akan optimal bila telah terdemposisi dengan sempurna. Untuk dapat tumbuh dan menghasilkan yang optimal, keluarga Zingiberaceae memerlukan tanah dengan kondisi fisik dan kimia yang baik. Sifat fisik tanah sangat penting artinya bagi komuditas yang berkaitan dengan produk yang dihasilkan yaitu berupa rimpang dimana akan berkembang dengan sempurna pada tanah-tanah gembur dan tidak padat serta bertekstur lemah.

Tabel 2. Pengaruh interaksi perlakuan jumlah umbi semu dan pupuk organik pada Pertumbuhan kunir putih (K. rotunda)

\begin{tabular}{|c|c|c|c|c|c|c|c|c|}
\hline $\begin{array}{l}\text { Kombinasi } \\
\text { Perlakuan }\end{array}$ & $\begin{array}{l}\text { Tinggi } \\
\text { Tanaman } \\
(\mathrm{cm})\end{array}$ & $\begin{array}{l}\text { Jumlah } \\
\text { daun }\end{array}$ & $\begin{array}{l}\text { Jumlah } \\
\text { tunas }\end{array}$ & $\begin{array}{l}\text { Jumlah } \\
\text { Umbi } \\
\text { semu }\end{array}$ & $\begin{array}{l}\text { Bobot bsh } \\
\text { Tajuk (g) }\end{array}$ & $\begin{array}{l}\text { Bobot krg } \\
\text { tajuk (g) }\end{array}$ & $\begin{array}{l}\text { Bobot bsh } \\
\text { rimpang }(\mathrm{g})\end{array}$ & $\begin{array}{c}\text { Bobot krg } \\
\text { rimpang(g) }\end{array}$ \\
\hline UOP0 & $90,67 \mathrm{a}$ & $10,33 \mathrm{a}$ & $2,33 \mathrm{~b}$ & $\begin{array}{ll}67 \quad \mathrm{a} \\
\end{array}$ & $128,53 \mathrm{a}$ & $\begin{array}{ll}7,9 & \mathrm{a}\end{array}$ & 273,37 a & $47,83 \mathrm{a}$ \\
\hline U2P0 & 87,67 a & $14,67 \mathrm{a}$ & $4,33 \mathrm{a}$ & 79 a & $199,8 \mathrm{a}$ & $15,33 \mathrm{a}$ & 359,50 a & 63,93 a \\
\hline U4P0 & $91 \quad \mathrm{a}$ & $12 \quad \mathrm{a}$ & $2,33 \mathrm{~b}$ & $73 \mathrm{a}$ & 201,3 a & $17 \quad \mathrm{a}$ & 306,37 a & 54,07 a \\
\hline U0P1 & $106,17 \mathrm{a}$ & $8,67 \quad b$ & $2,67 \mathrm{~b}$ & 60,67 & $168,5 \mathrm{~b}$ & 9,3 & 219,4 & $35,97 \mathrm{~b}$ \\
\hline $\mathrm{U} 2 \mathrm{P} 1$ & $107,17 \mathrm{a}$ & $22,33 \mathrm{a}$ & $6,33 \mathrm{a}$ & $101,33 \mathrm{a}$ & $483,8 \mathrm{a}$ & $32.63 \mathrm{a}$ & $540, .67 \mathrm{a}$ & $80,67 \mathrm{a}$ \\
\hline U4P1 & $101,16 \mathrm{a}$ & $18,67 \mathrm{~b}$ & $4,33 \mathrm{ab}$ & $91,3 \quad \mathrm{a}$ & $311,8 \mathrm{ab}$ & $17,37 \mathrm{ab}$ & 446,40 a & $63,07 \mathrm{ab}$ \\
\hline U0P2 & 89,33 & $14,67 \mathrm{a}$ & $4,67 \mathrm{a}$ & $63,3 \mathrm{a}$ & $160,3 \quad b$ & $10,87 \mathrm{~b}$ & $325,67 \mathrm{~b}$ & $63,37 \mathrm{a}$ \\
\hline $\mathrm{U} 2 \mathrm{P} 2$ & 102 a & $16,50 \mathrm{a}$ & & $85 \mathrm{a}$ & $419,10 \mathrm{a}$ & $28,15 \mathrm{a}$ & 525,8 a & 66,37 a \\
\hline U4P2 & 107,5 a & $11, .50 \mathrm{a}$ & $4, .5 \mathrm{a}$ & 90 a & $174,75 \mathrm{~b}$ & $12,60 \mathrm{~b}$ & $361,05 \mathrm{~b}$ & 66,37 a \\
\hline
\end{tabular}

Keterangan: Angka-angka yang diikuti dengan huruf yang sama pada lajur yang sama tidak berbeda nyata pada uji Duncan taraf $5 \%$

UOP0: Rimpang tanpa umbi semu tanpa penambahan pupuk organik

U2P0: Rimpang disertai 2 umbi semu tanpa penambahan pupuk organik

U4P0: Rimpang disertai 4 umbi semu tanpa penambahan pupuk organik

UOP1: Rimpang tanpa umbi semu dengan penambahan pupuk kandang

U2P1: Rimpang disertai 2 umbi semu dengan penambahan pupuk kandang

U4P1: Rimpang disertai 4 umbi semu dengan penambahan pupuk kandang

UOP2: Rimpang tanpa umbi semu dengan penambahan pupuk kompos

U2P2: Rimpang disertai 2 umbi semu dengan penambahan pupuk kompos

U4P2: Rimpang disertai 4 umbi semu dengan penambahan pupuk kompos 


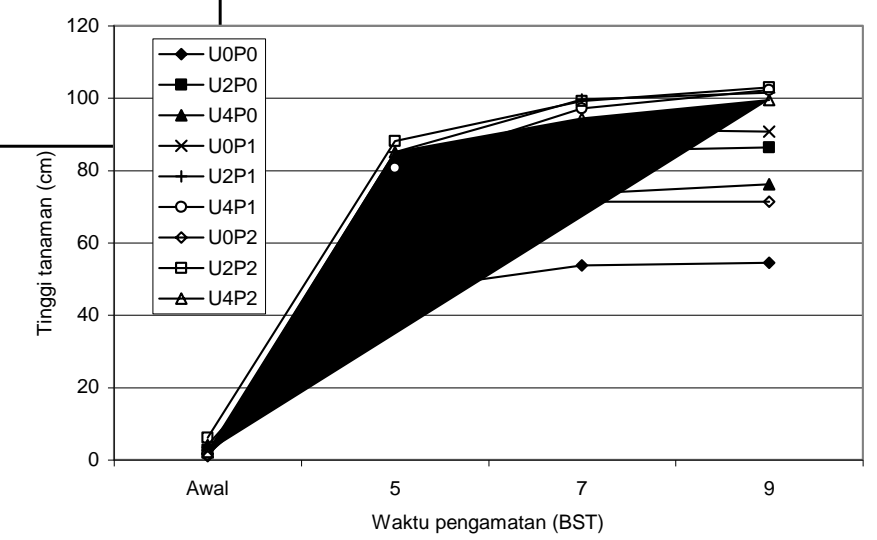

Gambar1. Laju pertambahan tinggi tanaman K.rotunda dengan perlakuan jumlah umbi semu dan pupuk organik

Produktifitas Kaempferia rotunda $L$.

Tabel 3. Hasil analisis tekstur dan kandungan N,.P dan K pada media tanam K.rotunda setelah penambahan pupuk organik

\begin{tabular}{lccc}
\hline \hline & Tanah & Pupuk kandang & Kompos \\
\hline \hline Tekstur (\%) & & & \\
Pasir & 50,4 & 53,2 & 55,0 \\
Debu & 26,1 & 26,7 & 25,2 \\
Liat & 23,5 & 20,1 & 19,8 \\
Kandungan hara & & & \\
N(\%) & 0,35 & 0,52 & 0,43 \\
P(ppm) & 48 & 65,20 & 78,80 \\
K (ppm) & 92,37 & 117,48 & 132,38 \\
pH(1:5) & & & \\
H2O & 7,05 & 6,54 & 6,34 \\
KCL & 6,85 & 6,21 & 6,18 \\
\hline
\end{tabular}

\section{Kesimpulan dan Saran}

Perlakuan jumlah umbi semu berpengaruh nyata terhadap produktivitas kunir putih, penambahan pupuk kandang memberikan hasil lebih baik dibandingkan kompos dan kontrol. Produktivitas tertinggi diperoleh pada kombinasi perlakuan 2 umbi semu dan penambahan pupuk kandang yang menghasilkan angka tertinggi pada semua peubah yang diamati yaitu tinggi tanaman $(107,17 \mathrm{~cm})$, jumlah anakan $(6,33)$, jumlah daun $(22,33)$, jumlah umbi semu $(101,33)$, bobot basah tajuk(483,8 g), bobot kering tajuk $(32,63 \mathrm{~g})$, bobot basah rimpang $(540,67 \mathrm{~g})$ dan bobot kering rimpang $(80,67 \mathrm{~g})$.

Untuk memperoleh produktivitas kunir putih yang optimal perlu dilakukan penelitian lanjutan dengan kombinasi perlakuan 2 umbi semu dan dosis pupuk kandang yang bervariasi.

\section{Ucapan Terima Kasih}

Penulis mengucapkan terima kasih kepada Bp.Ir. G. Panggabean M.Sc yang telah memberikan saran dan mengarahkan dalam penelitian ini.

\section{Daftar Pustaka}

Augusta, A. 2000. Minyak Atsiri Tumbuhan Tropika Indonesia. Penerbit TB Bandung.

Backer and Van den Brink RCB. 1968. Flora of Java vol.III. Groningen. Nordhoff Gronongen NVP The Nederlands.
Effendi, D.S., Januwati, M. dan Iskandar, M.1996. Pengaruh Tingkat Pemberian Pupuk Kandang dan beberapa MacamPembenah Tanah Buatan Terhadap Pertumbuhan dan Produksi Jahe (Zingiber officinale Rosc.). Pros.Simp.Nasional I Tumbuhan Obat dan Aromatic APINMAP. h:417-421

Hesce PR.1984. Potential of Organik Materials for Soil Improvement. IRRI.p:35-44

Kanonova, M.M. 1996. Soil Organik Matter Its Nature Its Role in soil Formation and Soil Fertility. Pergamon Press New York USA.

Materns, O.A. and Frankenberger, W.T. Jr. 1992. Modification of Infiltration Rates in an Organik-Amanded Soil. Jourmal American Society of Agronomy 84(4):707-717

Nartea, R.N. 1990. Basic Soil Fertility.UP Printery, Diliman. Philippines.

Noggle, G.R. and Fritz, G.J. 1983. Introductory Plant Physiology. Prentice Hall.Inc.New York.

Sastrapradja, 1977. Ubi-ubian. Proyek Sumber Daya Ekonomi Lembaga Biologi Nasional. LIPI. Bogor.

Sastroamidjojo, S. 1997. Obat Asli Indonesia. Dian Rakyat, Jsemuta. H:163

Salisbury, F.B. and Ross, C.W. 1991. Plant Physiology. Fourth Edition. Wodsworth Publishing Com.

Sumarmaini, E. Januwati, M. dan Iskandar, M. 1996. Studi Aplikasi Pupuk Kandang dan Sekam Pada Tanaman Kencur (Kaempferia galanga L.). Pros.Simpoium Nasional I Tumbuhan Obat dan Aromatik APINMAP : 467-472

Sumarni H-Priyono, Panggabean, G. dan Herlina, 2003. Pengaruh Pupuk Organik GM 50 Terhadap Pertumbuhan Kaempferia rotunda. Pros.Simpoium Nasional II Tumbuhan Obat dan Aromatik APINMAP : 294-297 